\title{
CASP3 Gene Product
}

National Cancer Institute

\section{Source}

National Cancer Institute. CASP3 Gene Product. NCI Thesaurus. Code C128276.

A protein encoded by the CASP3 gene. 